\title{
Individual migratory schedules and wintering areas of northern gannets
}

\author{
Ulrike Kubetzki ${ }^{1,2}$, Stefan Garthe ${ }^{1, *}$, David Fifield ${ }^{3,4}{ }_{\text {, Bettina Mendel }}{ }^{1}$, Robert W. Furness ${ }^{5}$ \\ ${ }^{1}$ Research and Technology Centre (FTZ), University of Kiel, Hafentörn 1, 25761 Büsum, Germany \\ ${ }^{2}$ Leibniz-Institute of Marine Research, IFM-GEOMAR, FB3 Fishery Biology, Düsternbrooker Weg 20, 24105 Kiel, Germany \\ ${ }^{3}$ Canadian Wildlife Service, Environment Canada, 6 Bruce St., Mount Pearl, Newfoundland A1N 4T3, Canada \\ ${ }^{4}$ Memorial University of Newfoundland, St. John's, Newfoundland A1C 5S7, Canada \\ ${ }^{5}$ Faculty of Biomedical and Life Sciences, Graham Kerr Building, University of Glasgow, Glasgow G12 8QQ, UK
}

\begin{abstract}
Individual migratory schedules and wintering areas of northern gannets Morus bassanus were studied over 2 consecutive winters by deploying geolocation data loggers on breeding adults from the Bass Rock, UK. Northern gannets attended the breeding colony on Bass Rock until between 24 September and 16 October (median: 5 October). Afterwards, individual birds engaged in different migratory behaviour. Of the 22 birds tracked until at least December, $18 \%$ wintered in the North Sea and the English Channel, $27 \%$ in the Bay of Biscay and the Celtic Sea, $9 \%$ in the Mediterranean Sea and $45 \%$ off West Africa. Individual winter home ranges as measured by the $75 \%$ kernel density contours varied between 8100 and $308500 \mathrm{~km}^{2}$ (mean $=134000 \mathrm{~km}^{2}$ ). Several northern gannets migrated northwards from Bass Rock after leaving the colony for a stay of a few days to a few weeks, independent of whether they migrated to Africa or other southern areas later. Birds wintering off West Africa migrated to their wintering areas mostly within 3 to $5 \mathrm{wk}$, usually starting between early and late October. Most of these birds stayed off West Africa for a period of about 3 mo, where they remained in a relatively restricted area. Return migration was initiated between the end of January and mid-February, and took about as long as autumn migration. We conclude that individual gannets display very variable migratory behaviours, with discrete winter home ranges, and we infer that the migration habits of gannets may be changing in response to human impacts on marine ecosystems.
\end{abstract}

KEY WORDS: Seabird $\cdot$ Migration $\cdot$ Winter $\cdot$ Geolocation $\cdot$ Home range $\cdot$ Fisheries

\section{INTRODUCTION}

Bird migration is a well-known and widespread phenomenon occurring on all continents and involving most bird taxa (Berthold 2001). While passerine and shorebird species perform well-defined migrations from distinct breeding areas to wintering areas, such migration habits are less obvious for many seabirds. Studying migration and winter distribution in seabirds is difficult, as these phenomena take place at sea and often involve huge distances, and are logistically very challenging. Most information on seabird migration has so far been based on ring recoveries and thus mainly on land-based recoveries of dead birds, or on ship-based surveys with mostly patchy survey effort. Ring recoveries give a valuable overview of the migration of species, but suffer from strongly varying spatial and temporal effort during re-sightings. Most ring recoveries originate from dead birds, informing us of the places where the birds died, rather than where they were living successfully. Recoveries may also be from places where the carcasses have been washed ashore and not necessarily where the birds died. Systematic studies of coastal seabird migration ('seawatching'; e.g. Camphuysen \& van Dijk 1983) and seabirds at sea censuses (e.g. Tasker et al. 1984) tend to give a biased pattern of the migratory behaviour because observation effort cannot be kept similar over 
vast areas, especially in the open sea, and seawatching data may be very weather dependent. Furthermore, the status and origin of individuals cannot be assessed, which could mean that birds found at sea in winter could breed in any colony of the respective species. Recent studies using data loggers have provided new insights into the migratory behaviour of large- and medium-sized seabirds such as penguins (e.g. Wilson et al. 1998), albatrosses (e.g. Grémillet et al. 2000, Phillips et al. 2005), shags (Daunt et al. 2006), shearwaters (Shaffer et al. 2006), petrels (Phillips et al. 2006, Rayner et al. 2008) and skuas (Phillips et al. 2007). The advantages of these devices is that geographic positions and behavioural parameters can be obtained without the need to watch the birds directly. Such devices have also substantially increased our knowledge on the individual behaviour of birds. Grémillet et al. (2000) and Weimerskirch \& Wilson (2000) found that albatrosses may exhibit distinct home range preferences during the non-breeding seasons that may or may not overlap with those of other individuals. Phillips et al. (2005) determined a high degree of site fidelity in grey-headed albatrosses Thalassarche chrysostoma, thus confirming winter site philopatry. Likewise, at much smaller spatial scales, consistent individual preferences for specific foraging areas or departure directions were found for black-legged kittiwakes Rissa tridactyla (Irons 1998) and northern gannets Morus bassanus (Hamer et al. 2001) during the breeding season. In Cory's shearwaters Calonectris diomedea, breeding populations clearly differed in their preference amongst their 3 major wintering areas, but showed substantial mixing (González-Solís et al. 2007).

Northern gannets are long-lived seabirds for which distribution and migratory movements have been documented from different data sources. Ring recoveries indicate that European adult northern gannets winter within a range from the North Sea, close to their main breeding sites, to southern Europe, with a high proportion of ring recoveries in winter in the North Sea, Celtic Sea and Bay of Biscay (Wernham et al. 2002). The Mediterranean Sea is also visited regularly in autumn and winter (Nelson 2002). Seawatching studies have revealed seasonal patterns in migratory and local movements of gannets at a few, selected coastal sites. These migratory patterns show periods of high migration intensity in autumn and spring and much smaller movements at other times of the year (Camphuysen \& van Dijk 1983), suggesting that migration is concentrated in certain periods of the year, but also that it varies over a few weeks among individuals and between years. Line transect surveys of seabird densities at sea have described the distribution of gannets over large areas of NW Europe, with particular focus on the
North Sea (Stone et al. 1995). These at-sea surveys demonstrate that adult gannets occur regularly in winter in the North Sea (e.g. Tasker et al. 1985), but also on the small continental shelf off (North-) West Africa (Camphuysen \& van der Meer 2005). Distribution patterns in the North Sea suggest alternative migratory routes in autumn and spring (Tasker et al. 1985). From observations in their principal North Sea breeding colony, the Bass Rock, Nelson (2002) found that northern gannets depart from late October to midNovember (Nelson 2002) and return there 'over a short period in mid-March' (J. Nelson pers. comm. in Tasker et al. 1985), although some individuals may return as early as January (Nelson 2002). The mean laying date is around mid-April, incubating takes about $6 \mathrm{wk}$, and chick-rearing, 13 wk (Nelson 2002).

Whilst data from ringing recoveries and at-sea surveys have provided useful insights into the winter distribution of gannets, a detailed understanding of individual migration and wintering strategies can only be achieved by attaching data loggers to individual birds over the non-breeding period. The wide range of wintering areas suggests that adult individuals show differences in their wintering areas and movements even when originating from the same breeding colony. We thus hypothesised that northern gannets from Bass Rock: (1) use different sea areas in winter, (2) spend the winter in rather restricted individual areas instead of migrating larger distances, and (3) exhibit individual routes and timing of migration. We investigated these hypotheses by deploying miniaturised electronic data loggers on chick-rearing adult gannets late in the breeding period at Bass Rock. Loggers were recovered early in the subsequent breeding season, yielding detailed information on individual over-winter movements. We discuss why gannets chose different wintering areas and how these are related to natural and anthropogenic variables.

\section{MATERIALS AND METHODS}

Data logger description. To study the movements over the non-breeding period, we deployed geolocation data loggers (GeoLT; Earth \& Ocean Technologies) on breeding adult northern gannets Morus bassanus from Bass Rock. The device was housed in a pressure-tight, seawater-resistant casing (diameter: $14 \mathrm{~mm}$; length: $45 \mathrm{~mm}$; weight: $8.2 \mathrm{~g}$, equivalent to ca. $0.3 \%$ of the bird body mass) and attached to a custombuilt leg band. Times of dawn and dusk were determined from a light sensor, allowing geographic position to be calculated from day length and time of local midday and midnight (e.g. Wilson et al. 1992, Hill 1994, Ekstrom 2004). The device's maximum sensitiv- 
ity was optimized for wavelengths penetrating deepest into clear coastal water, which minimizes the influence of submergence or atmospheric conditions, such as clouds or dust. Light levels were measured every $30 \mathrm{~s}$, allowing the device to operate for $1 \mathrm{yr}$ while providing 2 positional fixes per day. In addition to the light measurement, the GeoLT recorded ambient temperatures, (every $120 \mathrm{~s}$ ) throughout deployment.

Data logger deployment and working period. Chickrearing adult northern gannets on Bass Rock, Firth of Forth, Scotland $\left(56.078^{\circ} \mathrm{N}, 2.639^{\circ} \mathrm{W}\right)$ were equipped with geolocation loggers over 2 winter seasons; 15 devices were deployed in August 2002, and 26 devices were deployed on different individuals in August 2003. Of these, 13 were retrieved in April and May 2003 (first season), and 21 in April and May 2004 (second season). Tags were only recovered in accessible areas of the colony, but this allowed a high recovery rate, because almost all birds that were re-trapped nested at the same site in successive seasons (see Nelson 2002 for nest site fidelity).

Not all of the 34 loggers recovered functioned throughout the whole period of deployment. For both years combined, 65,32 and $18 \%$ of the devices worked until 30 November, 31 January and 31 March, respectively.

For all birds recaptured after the second season, sex was determined from blood samples using standard molecular methods (Griffiths et al. 1998).

Data logger analysis. The light data were analysed using MultiTrace Geolocation from Jensen Software Systems. Light levels were calibrated for sunrise and sunset from known locations (colony) and then applied to the whole dataset. Since our focus was on migratory movements rather than at-colony activity, analysis was restricted to the period from colony departure to colony return. Colony attendance was derived from logger temperature profiles, since they differ between birds on land and those in air or on water (for details see e.g. Wilson et al. 1995, Garthe et al. 2003).

Conventional geolocation analysis by light curves is hampered by inaccuracy of latitude estimation during equinoxes (e.g. Wilson et al. 1992, Hill 1994), such that reliable position determination during these periods is not directly possible. Also, latitude estimates are usually less accurate than longitude estimates. The achievable accuracy of this technique essentially depends on season and actual latitude and lies, for flying seabirds, in the order of 200 to $400 \mathrm{~km}$ (Phillips et al. 2004, Shaffer et al. 2005). To improve or generate latitude estimates we compared logger-measured sea surface temperatures (SSTs) with remotely sensed satellite SSTs using methods described by Teo et al. (2004) that have been validated for applications on seabirds (Shaffer et al. 2005). These methods work well in areas featuring north-south temperature gradients. Using these procedures, many positions from the equinox period were recovered. Furthermore, positions from other periods of the year were evaluated as well, and SST-corrected positions were taken where appropriate. The method of SST correction worked well in all areas except off West Africa due to strong east-west temperature gradients on the narrow continental shelf. In these cases, the original latitude values were retained. Furthermore, we filtered all datasets by excluding all positions that were $>700 \mathrm{~km}$ apart from the previous position based on the average flight speed of long-distance gannet flights of $58.4 \mathrm{~km} \mathrm{~h}^{-1}$ (Garthe et al. 2007) and unpublished data showing that our birds flew during $<50 \%$ of the $24 \mathrm{~h}$ day. As latitude values vary more than longitude values, even after the correction procedures mentioned above (the present analysis), we smoothed latitude values (see e.g. Pütz 2002) for migration and home range analysis (see below) by averaging data over 5 consecutive measurements. The 5 positions were weighted by a ratio of 3:2:1 for the current:last/next:previous-to-last/subsequent-to-next positions, respectively, to balance between the characteristics of the current day and possible improvements of the location by the adjacent measurements.

Latitude was chosen as the best indicator of migratory movements, since all birds migrated more or less due south. A smoothed latitude value was determined for each bird, for each $5 \mathrm{~d}$ period from the moment of colony departure until colony return or logger failure.

December was chosen as the most suitable time for 'winter', as basically all larger scale movements of gannets had ceased by the end of November and sample sizes decreased over time due to logger failures. Mean winter region position was defined as the mean of all locations obtained during the period 1 to 31 December ( $\mathrm{n}=22$ individuals). We also calculated winter home ranges for each of the birds that yielded at least 40 positions from 1 to 31 December ( $\mathrm{n}=18$ individuals). This number of positions was chosen both to cover the major part of the month and to guarantee a good sample size for each of the birds, but also to include some birds where the logger stopped working in late December. Because of the low accuracy of the positional calculations, we decided to use the $75 \%$ fixed kernel density for all positions in that period, using the Animal Movement Extension for ArcView (Hooge \& Eichenlaub 1997). Data were normalised between birds by always taking the first 40 positions in December of each individual for which these were available. Cell size for home range analysis was $10 \mathrm{~km}$. We used the ad hoc calculation of a kernel smoothing parameter provided by the Animal Movement Extension, as rec- 
ommended by Hooge \& Eichenlaub (1997). We also compared the individual home range with the combined home ranges for all 18 birds.

Generalised linear models (GLMs) were run to test for differences in direct distances from colony location to mean winter region position between years and sexes, as well as for home range sizes between winter regions using R 2.7.1 (R Development Core Team 2008).

\section{RESULTS}

\section{Device effects}

Recovery rates of devices from northern gannets Morus bassanus after 3 quarters of a year were very high $(87 \%$ after the first winter and $81 \%$ after the second winter), despite difficulties of landing on Bass Rock, which limited our search effort. Furthermore, these return rates were likely underestimates, as only a small part of the colony could be checked for birds with loggers, and at any single visit we could expect about half of the birds with loggers to be at sea rather than at the nest. Re-sightings were made only during 5 visits, each lasting 1 to $3 \mathrm{~h}$, in the early summers of 2003 and 2004. All birds with loggers that were seen breeding in the season after first capture were recaptured easily, and only 1 bird showed minor abrasions on the foot/leg where the device was attached. Only 1 gannet equipped with a logger was seen in the colony but not recaptured, and that individual was the only one (out of 35 known to be alive; $2.9 \%$ ) that was not breeding in the second season and did not seem to be holding a nest site. There is no reason to think that this bird was not breeding due to the presence of the logger, as a non-breeding rate of $2.9 \%$ is low compared to rates found among many long-lived seabirds (Catry et al. 1998). All 34 birds that were recaptured had an egg or a chick in the nest when recaptured. These recapture rates are substantially lower than the average annual adult survival rate. It cannot be resolved at this stage whether this is due to overlooking birds, due to device loss, due to relocation of nest sites of birds, or possibly due to elevated mortality. However, complete loss of a device plus attachment has been confirmed for an identical attachment procedure from 1 bird on Helgoland (in 2009; S. Garthe unpubl. data).

\section{Wintering areas and winter home ranges}

Northern gannets demonstrated individual variability in wintering areas. A few birds stayed in the North Sea, but most of them travelled further south (Table 1), with several birds going as far south as West Africa or as far east as the Mediterranean Sea (Fig. 1). From the 22 birds for which the winter region could be determined, $18 \%$ wintered in the North Sea and the English Channel; $27 \%$, in the Bay of Biscay and the Celtic Sea; $9 \%$, in the Mediterranean Sea; and $45 \%$, off West Africa (Table 1). Northern gannets travelled highly variable distances between colony and winter area (Table 1). The shortest direct distance between Bass Rock and the mean winter region position of a bird was $343 \mathrm{~km}$ and the largest distance was $4654 \mathrm{~km}$, with mean $( \pm$ SD) distances of $2171 \pm 1722 \mathrm{~km}$ in 2002/2003 ( $\mathrm{n}=10$ ) and $2766 \pm 1658 \mathrm{~km}$ in 2003/2004 ( $\mathrm{n}=12$ ). Differences between the 2 years were not significant (GLM; $t=0.814, \mathrm{p}=0.425)$. Although there was a tendency for females to winter further away from the breeding colony than males (mean \pm SD: male $=2485 \pm$ $1931 \mathrm{~km}, \mathrm{n}=6$; females $=3024 \pm 1629 \mathrm{~km}, \mathrm{n}=5$; see also Table 1), the difference could not be established statistically (GLM; $t=-0.487, \mathrm{n}=11, \mathrm{p}=0.638$ ), possibly due to the small sample size.

Table 1. Morus bassanus. Winter region, direct distance from colony to mean winter region position $(\mathrm{km})$ winter home range size (as measured by the $75 \%$ kernel density contour line) and sex of individual northern gannets equipped with geolocation data loggers on Bass Rock over the winter periods 2002/2003 and 2003/2004

\begin{tabular}{|c|c|c|c|c|c|}
\hline Year & Bird ID & Sex & Winter region & $\begin{array}{c}\text { Distance } \\
\text { to winter } \\
\text { region }(\mathrm{km})\end{array}$ & $\begin{array}{l}\text { Winter } \\
\text { range } \\
\left(\mathrm{km}^{2}\right)\end{array}$ \\
\hline \multirow{10}{*}{$2002 / 2003$} & 18 & $?$ & West Africa & 4654 & 288300 \\
\hline & 19 & $?$ & Bay of Biscay & 773 & - \\
\hline & 20 & $?$ & Bay of Biscay & 994 & 91800 \\
\hline & 24 & $?$ & Mediterranean Sea & 2244 & 13800 \\
\hline & 25 & $?$ & North Sea & 387 & - \\
\hline & 26 & $?$ & North Sea & 477 & 69500 \\
\hline & 27 & $?$ & Mediterranean Sea & 2422 & 36400 \\
\hline & 28 & $?$ & West Africa & 4371 & 116100 \\
\hline & 29 & $?$ & West Africa & 4378 & 31900 \\
\hline & 30 & $?$ & Bay of Biscay & 1014 & 81400 \\
\hline \multirow[t]{13}{*}{$2003 / 2004$} & 03 & $?$ & Bay of Biscay & 1044 & 139700 \\
\hline & 35 & Male & West Africa & 3167 & 55500 \\
\hline & 36 & Female & West Africa & 4467 & 70000 \\
\hline & 37 & Male & North Sea & 343 & 308500 \\
\hline & 42 & Male & West Africa & 4521 & - \\
\hline & 43 & Female & West Africa & 3941 & 82400 \\
\hline & 45 & Male & North Sea & 608 & 8100 \\
\hline & 47 & $?$ & West Africa & 4288 & 62400 \\
\hline & 48 & Female & Bay of Biscay & 1474 & 225900 \\
\hline & 49 & Male & West Africa & 3824 & - \\
\hline & 50 & Female & West Africa & 4196 & 167800 \\
\hline & 51 & Male & Bay of Biscay & 1324 & 132600 \\
\hline & All birds & & & & 1619000 \\
\hline
\end{tabular}



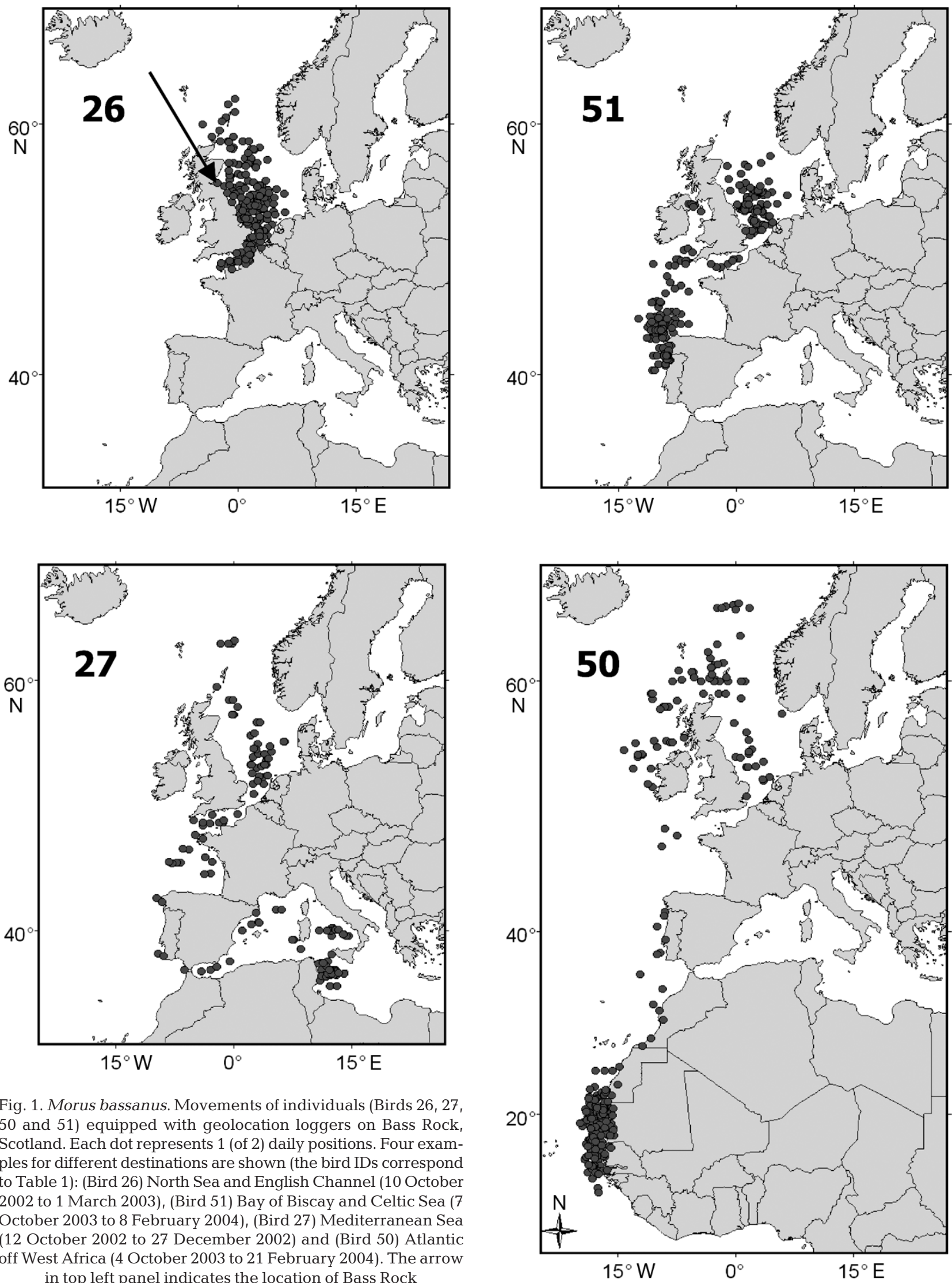

Fig. 1. Morus bassanus. Movements of individuals (Birds 26, 27, 50 and 51) equipped with geolocation loggers on Bass Rock, Scotland. Each dot represents 1 (of 2) daily positions. Four examples for different destinations are shown (the bird IDs correspond to Table 1): (Bird 26) North Sea and English Channel (10 October 2002 to 1 March 2003), (Bird 51) Bay of Biscay and Celtic Sea (7 October 2003 to 8 February 2004), (Bird 27) Mediterranean Sea (12 October 2002 to 27 December 2002) and (Bird 50) Atlantic off West Africa (4 October 2003 to 21 February 2004). The arrow in top left panel indicates the location of Bass Rock 
Individual winter home ranges as measured by the $75 \%$ kernel density contour line varied between 8100 and $308500 \mathrm{~km}^{2}$, with a mean $( \pm \mathrm{SD})$ of $134000 \pm$ $87800 \mathrm{~km}^{2}$ (Table 1). Differences between the different winter regions (Table 2) were not significant (GLM; $t=-0.122, \mathrm{p}=0.905)$, likely because of the small sample sizes. Individual home ranges of the 18 birds comprised $6.8 \pm 5.4 \%$ (range: 0.5 to $19.1 \%$ ) of the overall area of the 18 birds combined. This range is reduced to 0.1 to $4 \%$ when considering the whole biogeographic sea area from the North Sea to West Africa that is visited by the birds on migration and in winter.

\section{Migratory schedule and migratory routes}

Northern gannets attended the breeding colony on Bass Rock until between 24 September and 16 October ( $\mathrm{n}=24$, median: 5 October). Medians differed slightly between autumn 2002 ( 7 October, $\mathrm{n}=10$ ) and autumn 2003 (3 to 4 October, $\mathrm{n}=14$ ). Afterwards, individual birds engaged in different migratory behaviours. Birds that migrated south started their main migration on different dates (Fig. 2). Birds that were in the Bay of Biscay region in December showed variable approaches to the area, with one bird going to the northern North Sea first and another bird moving first to the more southerly Iberian Peninsula (as early as October). Birds wintering off West Africa migrated to their wintering areas mostly within 3 to $5 \mathrm{wk}$, usually starting between early and late October (Fig. 2). Most of these birds stayed off West Africa for a period of about 3 mo and remained in a relatively restricted area. Return migration was initiated between the end of January and midFebruary and took about as long as autumn migration (Fig. 2). There was not much variation in the timing when birds returned from the different winter regions: 2 March for 1 bird from the North Sea, 9 and 12 March for 2 birds from the Bay of Biscay, and 4, 6 and 15 March for 3 birds from West Africa.

Several northern gannets migrated northwards from Bass Rock after leaving the colony to stay in the northern North Sea and Norwegian Sea for a few days to a few weeks, independent of whether they migrated to Africa or other southern areas later (Fig. 2). Similarly, in spring, most birds with functioning loggers migrated to more northerly latitudes than their colony before returning to breed (Fig. 2). Of the 20 birds that migrated to West Africa, the Mediterranean Sea and the Bay of Biscay/Celtic Sea, 12 left the North Sea through the English Channel, while the remaining 8 migrated through the seas west of Scotland. In spring, 3 of the 9 gannets with functioning loggers came through the English Channel and the other 6 flew along the west coast of Scotland. Looking at the 9 individuals for which both periods could be tracked, individual responses are apparent: 2 birds using the channel in autumn also used the channel in spring; 3 birds using the area west of Scotland used the same area in spring; 1 bird flying south west of Scotland returned north through the channel, and the remaining 3 birds were birds that left the North Sea through the channel and came back west/north of Scotland.

\section{DISCUSSION}

\section{Methodology}

The method of geolocation involves relatively high inaccuracies compared to satellite telemetry and GPS logger technology, with lower errors for non-volant species (Wilson et al. 2002). Pütz et al. (1998) calcu-

Table 2. Morus bassanus. Sizes of winter home ranges per winter region. See Table 1 for data on individual birds; n: no of birds

\begin{tabular}{|lrrrrr|}
\hline Wintering region & $\mathrm{n}$ & $\begin{array}{r}\text { Mean } \\
\left(\mathrm{km}^{2}\right)\end{array}$ & $\begin{array}{r}\mathrm{SD} \\
\left(\mathrm{km}^{2}\right)\end{array}$ & $\begin{array}{r}\text { Minimum } \\
\left(\mathrm{km}^{2}\right)\end{array}$ & $\begin{array}{r}\text { Maximum } \\
\left(\mathrm{km}^{2}\right)\end{array}$ \\
\hline North Sea/English Channel & 3 & 128700 & 158700 & 8100 & 308500 \\
Bay of Biscay/Celtic Sea & 5 & 134300 & 57100 & 81400 & 225900 \\
Mediterranean Sea & 2 & 25100 & 16000 & 13800 & 36400 \\
West Africa & 8 & 109300 & 83500 & 31900 & 288300 \\
\hline
\end{tabular}

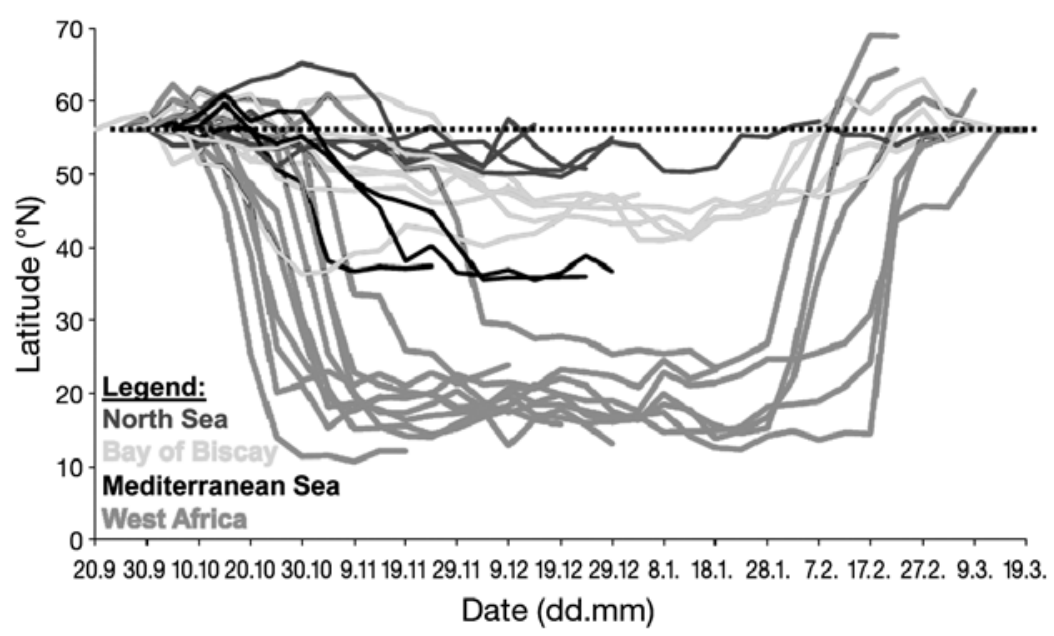

Fig. 2. Morus bassanus. Timing of movements of individuals showing smoothed mean latitude for each bird during standardized $5 \mathrm{~d}$ periods. The dotted line indicates latitude of the Bass Rock colony 
lated an error of $31.3 \pm 30.6 \mathrm{~km}$ when comparing lightbased locations and satellite-derived locations for king penguins Aptenodytes patagonicus. Phillips et al. (2004) determined, for black-browed albatrosses Thalassarche melanophrys, an average error without data smoothing of $186 \pm 114 \mathrm{~km}$ for trials on birds and $85 \pm 47 \mathrm{~km}$ for static trials. Shaffer et al. (2005) found even higher errors working with 2 albatross species in the North Pacific. The mean $( \pm \mathrm{SD})$ difference between lightbased location and satellite-based location was $400 \pm$ $298 \mathrm{~km}$. Errors in geolocation positions were reduced to $202 \pm 171 \mathrm{~km}$ when light-based longitude and SSTbased latitude were combined to establish locations (Shaffer et al. 2005). Large inaccuracies were also visible in our raw data sets, and both SST correction and data filtering are likely to have improved our position estimates based on findings from Phillips et al. (2004) and Shaffer et al. (2005).

\section{Winter distribution and home ranges}

The large number of birds migrating from Bass Rock to West Africa is surprising, especially when compared to the very small number of ring recoveries from that part of the world (Nelson 2002, Wanless 2002), although numerous recoveries exist for other species from the area (Wernham et al. 2002). This also indicates possible changes in the wintering behaviour of Bass Rock gannets Morus bassanus. Although our sample sizes are relatively small, the similar results in both study years support the conclusion that these patterns are representative of the large breeding colony on Bass Rock in recent years.

Despite some local movements, most individuals spent the winter period in relatively small, welldefined winter home ranges. This was particularly true for the period from early December to mid-January. In November some birds were still migrating (Fig. 2) (but at a slower rate than in October), while several birds had already reached their final destination. These birds might have sampled other areas for possible wintering. The wide range of distinct wintering regions and the relatively small winter home ranges in comparison to the overall wintering area, confirm our first 2 hypotheses: that different gannets migrate to different areas and tend to stay in discrete wintering areas.

\section{Migration}

Gannets that migrated furthest showed a general pattern of flying from slightly north of $50^{\circ} \mathrm{N}$ latitude to $20-23^{\circ} \mathrm{N}$ latitude fairly quickly and at a relatively constant speed of 250 to $450 \mathrm{~km} \mathrm{~d}^{-1}$. However, the timing of this migration varied between individuals by almost a month. Individuals also exhibited individual migratory routes. Several individuals flew north for variable periods after leaving Bass Rock, while others departed south. Also, while birds tended to leave the North Sea through the English Channel (rather than west of Scotland) and tended to return through the seas off western Scotland (rather than through the English Channel), an observation that is confirmed from distribution patterns of birds at sea (Tasker et al. 1985) and from seawatching studies in the Netherlands (Camphuysen \& van Dijk 1983), there were individual differences that were independent of their final wintering area. These findings all confirm our third hypothesis that routes and timing of migrations vary among individuals.

\section{Distribution, prey resources and anthropogenic pressures}

The winter distribution of gannets as well as their migratory corridors match well with areas of high productivity (e.g. Mann \& Lazier 2006). The area used most commonly in our study is a near-coastal area off (North-)West Africa. This area is part of a large upwelling zone extending along the coast of NW Africa (van Camp et al. 1991, Nykjær \& van Camp 1994). As large pelagic fish comprise the most important prey of gannets (Nelson 2002), it is of little surprise that the shelf sea and the shelf break areas off West Africa may offer a rich food supply of such energy-rich fish. This is also apparent due to the occurrence of intense pelagic fisheries off West Africa, targeting Sardinella aurita, Sardinella maderensis, Sardina pilchardus, Scomber japonicus and Trachurus trecae (ter Hofstede \& Dickey-Collas 2006).

Earlier studies have shown that gannets may also use fishery discards to a substantial degree (e.g. Tasker et al. 1987, Camphuysen et al. 1995, Käkelä et al. 2007). The availability of discards may thus be another important factor influencing their winter distribution. Crane (2005) investigated how much food may be made available to seabirds as fishery discards in different regions, mainly from demersal fisheries. He reviewed the literature and analysed the Food and Agricultural Organisation's database to find information on discard rates in different fisheries and regions. Overlaying our winter regions with the discard data shown in Crane (2005) revealed that remarkably high proportions of northern gannets stayed in areas of elevated discard rates. This is strongly corroborated by the observations of Camphuysen \& van der Meer (2005), who found that $88.8 \%$ of the northern gannets wintering off the western Sahara and Mauritania were 
associated with commercial fishing vessels. West African fisheries have developed strongly over the last 2 decades and produce substantial amounts of discards (Kaczynski \& Fluharty 2002, Alder \& Sumaila 2004, Crane 2005).

Altogether, these data and observations suggest that areas outside the North Sea offer sufficient food for northern gannets from natural and anthropogenic sources. If, as a consequence of the current high fishing effort, fish stocks off West Africa become depleted, it is to be expected that the attractiveness of the West African winter region for gannets may diminish in the future-directly by overfishing of pelagic fish stocks and indirectly by reducing the amounts of discards due to regulations that reduce fishing effort.

\section{Perspectives}

Further investigations are needed to elucidate the advantages and disadvantages for gannets to stay close to their breeding site (i.e. in the North Sea) or to undertake migratory movements to distant wintering areas. This may include comparisons of diets (e.g. Phillips et al. 2007), activity rhythms (e.g. Daunt et al. 2006), and food availability (e.g. Hamer et al. 2001). Additionally, studies of individual consistency in migratory schedules and wintering areas would help to further unravel the migratory strategies of northern gannets.

Acknowledgements. The present study was part of the EUfunded project 'DISCBIRD' ('Effects of changes in fishery discarding rates on seabird communities', Contract Q5RS-200100839). Ophelia Engelhard, Jon Crane and Steve Votier helped with field work. Molecular sexing was carried out by Kate Griffiths. Sir Hew Hamilton-Dalrymple allowed us to work on Bass Rock, and the Marr family provided safe transport to and from the island. G. Peters and 3 anonymous referees made valuable comments on an earlier version of this manuscript.

\section{LITERATURE CITED}

Alder J, Sumaila UR (2004) Western Africa: a fish basket of Europe past and present. J Environ Dev 13:156-178

Berthold P (2001) Bird migration: a general survey. Oxford University Press, Oxford

Camphuysen CJ, van der Meer J (2005) Wintering seabirds in West Africa: foraging hotspots off western Sahara and Mauritania driven by upwelling and fisheries. S Afr J Mar Sci 27:427-437

Camphuysen CJ, van Dijk J (1983) Zee- en kustvogels langs de Nederlandse kust, 1974-79. Limosa 56:81-230

Camphuysen CJ, Calvo B, Durinck J, Ensor K and others (1995) Consumption of discards by seabirds in the North Sea. Final report EC DG XIV Research Contract BIOECO/93/10. NIOZ-Rep. 1995-5, Netherlands Institute for Sea Research, Texel

Catry P, Phillips RA, Hamer KC, Ratcliffe N, Furness RW (1998) The incidence of nonbreeding by adult great skuas and parasitic jaegers from Foula, Shetland. Condor 100: 448-455

Crane JE (2005) Relationships between fisheries, breeding and migration of the great skua Stercorarius skua. PhD thesis, University of Glasgow, Glasgow

Daunt F, Afanasyev V, Silk JRD, Wanless S (2006) Extrinsic and intrinsic determinants of winter foraging and breeding phenology in a temperate seabird. Behav Ecol Sociobiol 59:381-388

Ekstrom PA (2004) An advance in geolocation by light. Mem Natl Inst Polar Res (Jpn) B 58(Spec Issue):210-226

Garthe S, Benvenuti S, Montevecchi WA (2003) Temporal patterns of foraging activities of northern gannets Morus bassanus in the north-west Atlantic. Can J Zool 81: 453-461

Garthe S, Montevecchi WA, Davoren G (2007) Flight destinations and foraging behaviour of northern gannets (Sula bassana) preying on a small foraging fish in a Low Arctic ecosystem. Deep Sea Res Part II 54:311-320

> González-Solís J, Croxall JP, Oro D, Ruiz X (2007) Transequatorial migration and mixing in the wintering areas of a pelagic seabird. Front Ecol Environ 5:297-301

Grémillet D, Wilson RP, Wanless S, Chater T (2000) Blackbrowed albatrosses, international fisheries and the Patagonian Shelf. Mar Ecol Prog Ser 195:269-280

Griffiths R, Double MC, Orr K, Dawson RJG (1998) A DNA test to sex most birds. Mol Ecol 7:1071-1075

Hamer KC, Phillips RA, Hill JK, Wanless S, Wood AG (2001) Contrasting foraging strategies of gannets Morus bassanus at two North Atlantic colonies: foraging trip duration and foraging area fidelity. Mar Ecol Prog Ser 224: 283-290

Hill RD (1994) Theory of geolocation by light levels. In: Le Boeuf BJ, Laws RM (eds) Elephant seals: population ecology, behavior, and physiology. University of California Press, Berkeley, p 227-236

Hooge PN, Eichenlaub B (1997) Animal movement extension to Arcview, Ver. 1.1. Alaska Science Center-Biological Science Office, U.S. Geological Survey, Anchorage, AK

Irons DB (1998) Foraging area fidelity of individual seabirds in relation to tidal cycles and flock feeding. Ecology 79: 647-655

Kaczynski VM, Fluharty DL (2002) European policies in West Africa: who benefits from fisheries agreements? Mar Policy 26:75-93

Käkelä A, Furness RW, Kelly A, Strandberg U, Waldron S, Käkelä R (2007) Fatty acid signatures and stable isotopes as dietary indicators in North Sea seabirds. Mar Ecol Prog Ser 342:291-301

Mann KH, Lazier JRN (2006) Dynamics of marine ecosystems. Biological-physical interactions in the oceans. Blackwell Science, Oxford

Nelson JB (2002) The Atlantic gannet. Fenix Books, Norfolk

> Nykjær L, van Camp L (1994) Seasonal and interannual variability of coastal upwelling along northwest Africa and Portugal from 1981 to 1991. J Geophys Res 99(C7): 14197-14207

> Phillips RA, Silk JRD, Croxall JP, Afanasyev V, Briggs DR (2004) Accuracy of geolocation estimates for flying seabirds. Mar Ecol Prog Ser 266:265-272

> Phillips RA, Silk JRD, Croxall JP, Afanasyev V, Bennett VJ (2005) Summer distribution and migration of nonbreeding albatrosses: individual consistencies and implications for conservation. Ecology 86:2386-2396 
Phillips RA, Silk JRD, Croxall JP, Afanasyev V (2006) Yearround distribution of white-chinned petrels from South Georgia: relationships with oceanography and fisheries. Biol Conserv 129:336-347

Phillips RA, Catry P, Silk JRD, Bearhop S, McGill R, Afanasyev V, Strange IJ (2007) Movements, winter distribution and activity patterns of Falkland and brown skuas: insights from loggers and isotopes. Mar Ecol Prog Ser 345:281-291

Pütz K (2002) Spatial and temporal variability in the foraging areas of breeding king penguins. Condor 104:528-538

Pütz K, Wilson RP, Charrassin JB, Raclot T and others (1998) Foraging strategy of king penguins (Aptenodytes patagonicus) during summer at the Crozet Islands. Ecology 79:1905-1921

R Development Core Team (2008) R: a language and environment for statistical computing. R Foundation for Statistical Computing, Vienna. Available at: www.R-project.org

Rayner MJ, Hauber ME, Clout MN, Seldon DS, van Dijken S, Bury S, Phillips RA (2008) Foraging ecology of the Cook's petrel Pterodroma cookii during the austral breeding season: a comparison of its two populations. Mar Ecol Prog Ser 370:271-284

Shaffer SA, Tremblay Y, Awkerman JA, Henry RW and others (2005) Comparison of light- and SST-based geolocation with satellite telemetry in free-ranging albatrosses. Mar Biol 147:833-843

Shaffer SA, Tremblay Y, Weimerskirch H, Scott D, and others (2006) Migratory shearwaters integrate oceanic resources across the Pacific Ocean in an endless summer. Proc Natl Acad Sci USA 103:12799-12802

Stone CJ, Webb A, Barton C, Ratcliffe N and others (1995) An atlas of seabird distribution in north-west European waters. Joint Nature Conservation Committee, Peterborough

Tasker ML, Jones PH, Dixon T, Blake BF (1984) Counting seabirds at sea from ships: a review of methods employed and a suggestion for a standardized approach. Auk 101: $567-577$

Tasker ML, Jones PH, Blake BF, Dixon TJ (1985) The marine distribution of the gannet Sula bassana in the North Sea. Bird Study 32:82-90

Editorial responsibility: Jacob Gonzáles-Solís, Barcelona, Spain
Tasker ML, Webb A, Hall AJ, Pienkowski MW, Langslow DR (1987) Seabirds in the North Sea. Final report of Phase 2 of the Nature Conservancy Council's Seabirds at Sea Project, November 1983-October 1986. Nature Conservancy Council, Peterborough

Teo SLH, Boustany A, Blackwell SB, Walli A, Weng KC, Block BA (2004) Validation of geolocation estimates based on light level and sea surface temperature from electronic tags. Mar Ecol Prog Ser 283:81-98

ter Hofstede R, Dickey-Collas M (2006) An investigation of seasonal and annual catches and discards of the Dutch pelagic freezer-trawlers in Mauritania, Northwest Africa. Fish Res 77:184-191

> van Camp L, Nykjær L, Mittelstaedt E, Schlittenhardt P (1991) Upwelling and boundary circulation off Northwest Africa as depicted by infrared and visible satellite observations. Prog Oceanogr 26:357-402

Wanless S (2002) Northern gannet Morus bassanus. In: Wernham CV, Toms M, Marchant J, Clark J, Siriwardena G, Baillie $S$ (eds) The migration atlas: movements of the birds of Britain and Ireland. Poyser, London, p 130-132

Weimerskirch H, Wilson RP (2000) Ocean respite for wandering albatrosses. Nature 406:955-956

Wernham CV, Toms M, Marchant J, Clark J, Siriwardena G, Baillie S (eds) (2002) The migration atlas: movements of the birds of Britain and Ireland. Poyser, London

Wilson RP, Ducamp JJ, Rees WG, Culik BM, Nickamp K (1992) Estimation of location: global coverage using light intensity. In: Priede IG, Swift SM (eds) Wildlife telemetry: remote monitoring and tracking of animals. Ellis Horwood, New York, p 131-134

Wilson RP, Weimerskirch H, Lys P (1995) A device for measuring seabird activity at sea. J Avian Biol 26:172-175

> Wilson RP, Alvarrez B, Latorre L, Adelung D, Culik B, Bannasch R (1998) The movements of gentoo penguins Pygoscelis papua from Ardley Island, Antarctica. Polar Biol 19: 407-413

- Wilson RP, Grémillet D, Syder J, Kierspel MAM and others (2002) Remote-sensing systems and seabirds: their use, abuse and potential for measuring marine environmental variables. Mar Ecol Prog Ser 228:241-261

Submitted: May 14, 2008; Accepted: July 31, 2009

Proofs received from author(s): September 15, 2009 